\title{
Investigating the Reading Strategies Used by French Immersion Pupils as They Engage With Dual-Language Children's Books: A Multiple Case Study
}

\author{
Joël Thibeault ${ }^{1}$ and Ian A. Matheson ${ }^{2}$ \\ ${ }^{1}$ University of Ottawa \\ ${ }^{2}$ Queen's University
}

\section{Authors' Note}

Joël Thibeault, Faculty of Education, University of Ottawa

Ian A. Matheson ๑ https://orcid.org/0000-0003-1060-6172

Correspondence regarding this article should be directed to Joël Thibeault at joel.thibeault@uottawa.ca or Ian A. Matheson atian.matheson@queensu.ca

\begin{abstract}
As dual-language children's books are becoming increasingly popular in language and literacy education, scholars are starting to zero in on how students construct meaning as they read these books. In this paper, in light of the previously mentioned body of literature, we present a qualitative study focusing on the reading strategies that three Grade 3 French immersion pupils schooled in Saskatchewan deployed when they read two types of dual-language books: translated, where the entire text appears in both English and French, and integrated, where passages in French organically complete those in English without providing the exact same information. This multiple case study highlights three distinct reading profiles, and shows how monolingual and cross-linguistic reading strategies can be used by the same student as they read a dual-language book. It also shows that some students were able to adapt their reading strategies as they engaged with different types of dual-language books, whereas others more frequently utilized the same strategies.
\end{abstract}

Keywords: dual-language children's books, reading strategies, French immersion

\section{Résumé}

Alors que les livres bilingues deviennent de plus en plus populaires en didactique des langues, la recherche commence à s'intéresser aux comportements cognitifs de l'élève qui s'engage dans la lecture de ces œuvres. Dans cet article, à la lumière de ces études, nous relatons les résultats d'une recherche qualitative visant à décrire les stratégies de lecture que trois élèves de $3^{\mathrm{e}}$ année scolarisés en Saskatchewan en immersion française déploient lorsqu'ils lisent deux types de livres bilingues : le livre traduit, dans lequel tout le texte apparait en français et en anglais, et le livre intégré, dans lequel le texte en français complète celui en anglais, sans toutefois offrir au lecteur la même information. Cette étude de cas multiple relève donc trois profils distincts de lecteur et, par son entremise, nous montrons comment des stratégies de lecture monolingues et translinguistiques peuvent être utilisées par un même élève lorsqu'il lit un livre bilingue. Nous révélons en outre que certains élèves sont à même d'adapter leurs stratégies de lecture selon le type de livre bilingue lu, tandis que d'autres font fréquemment usage des mêmes stratégies.

Mots-clés : livres bilingues, stratégies de lecture, immersion française

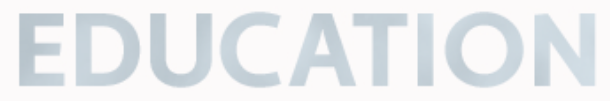




\section{Investigating the Reading Strategies Used by French Immersion Pupils as They Engage With Dual-Language Children's Books: A Multiple Case Study}

Reading is a fundamental component of education systems. Through reading instruction, students not only acquire the skills and attitudes to make meaning out of text, they also develop the capacity to construct knowledge related to literacy and other disciplines. In French immersion programming, pupils simultaneously learn how to read in both French and English, and the abilities they develop transfer from one language to the other. As this program is becoming increasingly popular throughout Canada, scholars have started to zero in on the acquisition of reading skills by French immersion students, and have looked to identify teaching methods and approaches that reflect their characteristics. In this perspective, for this paper, we aim to explore French immersion students' use of reading strategies while they read a type of text that is gaining traction in language and literacy education research: dual-language books.

\section{Theoretical Framework and Literature Review}

Research on reading acquisition has notably highlighted that dynamic thinking-active and conscious decision-making on how to effectively build meaning from a particular text - is a quality of good reading (Matheson \& MacCormack, 2021; Paris \& Jacobs, 1984). It should, therefore, come as no surprise that such dynamic thinking is recognized as being effective in both monolingual and bilingual reading contexts. In fact, readers who actively use their first language (L1) as a tool for making sense of text in their second language (L2) usually gain more success in reading (Cisco \& Padrón, 2012; Jiménez et al., 1996). In other words, readers who acknowledge that cognitive transfers between L1 and L2 provide them with powerful opportunities to make meaning out of text can rely on a wider variety of skills and knowledge to do so.

Whereas research in immersion is starting to recognize that we should teach for transfer (Cummins, 2008), there seems to be a culture of monolingualism that prevails in French immersion contexts (Cormier, 2018). To make sure that students can benefit from the program, teachers seem to emphasize and prioritize a complete exposure to the students' second language. If a predominately francophone environment remains one of the underlying traits of French immersion classrooms, Swain and Lapkin (2013) contend that teachers can draw upon their students' knowledge of English to enhance their linguistic repertoire and teach them how to strategically use it when they are learning French. Ballinger (2013), through the implementation of a biliteracy project in French immersion, further noted that students who took part in this biliteracy initiative were able to reciprocally employ strategies that could be used in both English and French as they were completing different language tasks.

This body of literature encouraged us to consider the resources that teachers can utilize in order to support students as they transfer their knowledge and skills from one language to the other in French immersion contexts. One promising approach for L2 learning using the learner's L1 is through the use of dual-language children's books. These books, which contain different languages, can therefore allow for active and conscious decision making about how to use one language for reading and learning in the other (Armand et al., 2016; Simoncini et al., 2019). While some research has begun to examine how readers engage with dual-language texts (e.g., Sneddon, 2009), Thibeault and Matheson (2020) identified a paucity of studies focused more specifically on French immersion. 


\section{Second Language Reading}

Reading comprehension is built through the use of goal-oriented cognitive or physical actions focused on decoding text and constructing meaning-these actions, which represent a fundamental part of the dynamic thinking mentioned in the previous section, are known as reading strategies (Aydinbek, 2021; Turcotte et al., 2015). Research on reading strategies notably distinguishes between effective and ineffective reading behaviours; good readers would use reading strategies both more often and more effectively than poor readers (Anastasiou \& Griva, 2009; Lau, 2006). It is noteworthy, moreover, that effective readers make adjustments to their application of strategies in response to the demands of the text (Mokhtari \& Sheorey, 2002). This information also reflects the findings of researchers who focused on second language readers. These scholars, moreover, have highlighted the role of the languages known by the reader as they engage in a second language reading task. Effective bilingual readers would therefore shift among their L1 and L2, translating from one language to the other, and using specific features of the L2 text to signal specific strategy use, such as drawing on cognate vocabulary (Alsheikh, 2011; Jiménez et al., 1996).

In the specific context of French immersion, Bourgoin (2015) found that elementary-aged French immersion students that were effective readers transferred strategies across their L1 and L2. In other words, students who understand that certain strategies (e.g., predicting, rereading) can be used in both French and English would tend to be more effective readers. Frid (2018) further showed that French immersion readers deployed different types of strategies when they read an English or a French text. In French, they more frequently recruit text-based strategies such as necessary inferencing and summarizing. On the other hand, strategies such as predicting and references to background knowledge, which may enable the student to consolidate the text to memory, were utilized more often in English.

Research focusing on the reading strategies deployed by French immersion learners thus shows that efficient readers transfer strategies from one language to the other as they engage in a reading task and that the same reader may use a different set of strategies depending on the language in which the text is written. In light of this, we can wonder whether the use of duallanguage books can allow the reader to use their entire repertoire of strategies as they read the text and, more broadly, whether the presence of two languages in the book can provide opportunities for them to easily make cross-linguistic connections when they read.

\section{Dual-Language Books}

Dual-language books are text in which two languages cohabit to a certain degree, and both languages are intended to be read simultaneously by the reader. Perregaux (2009), alongside Ernst-Slavit and Mulhern (2003), also distinguished between different types of dual-language texts. One type, which we refer to as a "translated text," includes equal representation of both languages throughout the entire text. Alternatively, a type we refer to as "integrated texts" contains both languages, though not as equivalent passages. These passages may work together to forward the text narrative in an embedded and organic way, such as with two characters that speak different languages.

Dual-language books are increasingly being examined by researchers due to their potential for leveraging skills in one language in order to scaffold learning and reading in the other (Simoncini et al., 2019; Taylor et al., 2008). Scholars have praised these texts for their potential for legitimizing cultural and linguistic diversity, and constructing a sense of community 
(Fleuret \& Sabatier, 2019; Moore \& Sabatier, 2014), let alone the literacy benefits related to vocabulary development (Gosselin-Lavoie, 2016; Read et al., 2021), metalinguistic awareness (Robertson, 2006; Thibeault \& Quevillon-Lacasse, 2019), and graphophemic knowledge (Naqvi et al., 2012).

Sneddon (2009) appears to have been one of the first authors to examine reading strategy use specifically with dual-language texts; according to her findings, the strategies that helped readers the most with constructing meaning varied according to their language background and competence with the languages at play, as well as how closely related the languages in the book were on a linguistic level. More recently, Domke (2019) described the reading strategies that Grade 3 and Grade 5 bilingual Spanish-English students schooled in the United States used as they read a translated text. She focused on the strategies used to translate words and retell passages. Results show that younger students used strategies which tended to focus on text features (e.g., position of words on the page), while older students more frequently used strategies that are connected to the languages they knew (e.g., grammatical inference).

In our previous research (Thibeault \& Matheson, 2020), we also documented the crosslinguistic strategy use of elementary-aged French immersion students as they read dual-language texts. Cross-linguistic strategies are behaviours that rely on the interaction of the languages found in the book, unlike their monolingual counterparts, which rely exclusively on one language. We identified that readers collectively used equivalent passages in one language to assist with passages in the other, used potential cognates to indicate what a particular word might mean, and used context within one language to assist with meaning construction in another language. Some readers also identified structural features of the dual-language text in order to determine how they should read it; these students determined whether or not French and English passages were direct translations of each other, or altogether separate passages that worked together to tell the story. We further discovered that the use of these cross-linguistic strategies varied for some participants according to what type of dual-language text they were reading. Some of our participants did not adjust their reading strategies when reading the integrated text - they would, for example, look for a direct translation and, as a result, experience comprehension gaps as they read.

Despite the identified value of using dual-language texts as educational tools, there is still much to learn about how bilingual children engage with dual-language books. While we are beginning to understand the repertoire of strategies that students use while reading (Domke, 2019; Sneddon, 2009), and with particular types of text (Thibeault \& Matheson, 2020), we need to further examine how these strategies are being used with dual-language children's books, specifically in French immersion contexts. In this paper, we therefore aim to build on our previous work, which focused exclusively on cross-linguistic strategies, to examine how elementary-aged French immersion students use reading strategies-both monolingual and cross-linguistic. To do so, we will also focus on two types of dual-language books: translated and integrated. More specifically, we wish to answer the following two questions:

1. What are the reading strategies that elementary students in French immersion use while reading different types of dual-language French/English children's books (i.e., translated and integrated texts)?

2. How do these students use reading strategies when they engage with each type of duallanguage children's book (i.e., translated and integrated texts)? 


\section{Methodology}

In order to thoroughly describe the strategies that elementary students used when they read two types of dual-language books, we opted for an exploratory and descriptive multiple case study approach (Duff, 2008). The initial study was composed of 16 Grade 3 and 4 students who were schooled in a Saskatchewan city centre in two different split classrooms. These classrooms were located in two schools within relatively affluent neighborhoods. Students predominantly spoke English with their parents and siblings, but some of them declared French and Urdu as languages used at home.

From the larger sample, we identified three students in Grade 3-Kaya, Maria, and Karly - as rich cases. As part of a larger study focused on understanding the strategies, thoughts, and behaviours of elementary-aged French Immersion students as they read dual-language children's books (Thibeault \& Matheson, 2020), these cases were selected because the students, through data collection, provided clear insight into their varied strategy use and reading behaviours, as well as their intentions. As can be seen in the results section, these three participants also obtained different scores at the comprehension tests they had to complete after reading the integrated and translated dual-language book.

Figure 1

Cover of Enchantée!/Pleased to meet you! (Brunelle \& Tondino, 2017)

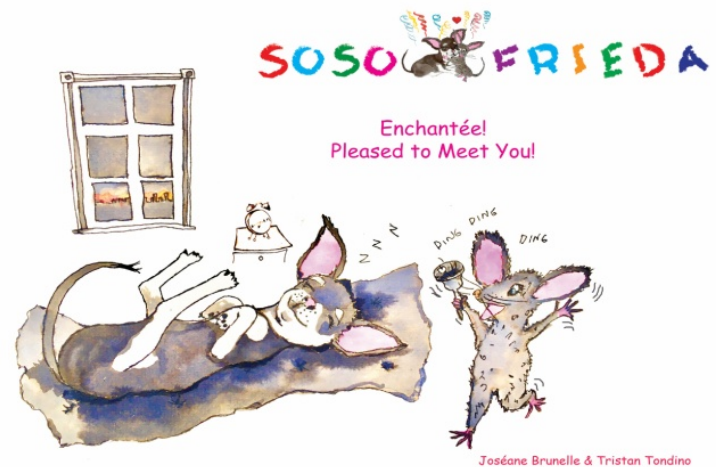

Data collection took place during class time; participants were met individually by a member of the research team in a meeting room near their classroom. They were asked to read passages of two books for this study: one translated dual-language book, the other integrated. The translated text style used in this research is characterized by parallel French and English text; the story is told in both languages word for word, and our participants read this text first. We chose a book entitled Enchantée! Pleased to Meet You! (Brunelle \& Tondino, 2017; see Figures 1 and 2), because it was the appropriate reading level for the participants. In this particular book, the French text appears in pink on the left side of the page above the same text in English, and an image always appears on the right page. The story depicted the relationship of a pet Chihuahua named Soso and a mouse named Frieda. Contrastingly, the integrated text style is characterized by non-equivalent French and English text; each language is used to tell a different part of the story, and our participants read this text second. Our participants read Chez Betty \& Cat at Home (Jacobs \& Duvernois, 2016; see Figure 3), again selected for its ageappropriateness. Both the French text and the English text appear on the same page again, and images accompany each page of text. The story focuses on the coexistence of an English- 
speaking cat named Cat and a French-speaking dog named Betty, who each tell the same story using their own unique perspective of the events.

Figure 2

Passage of Enchantée!/Pleased to meet you! (Brunelle \& Tondino, 2017)
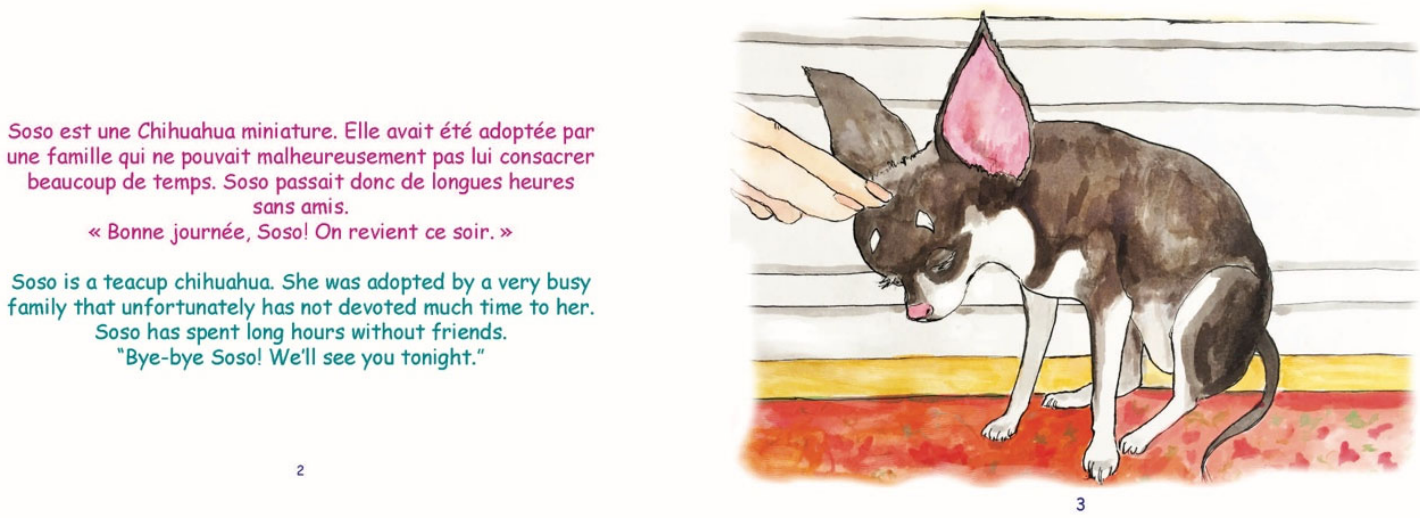

Figure 3

Cover and passage of Chez Betty \& Cat at home (Jacobs \& Duvernois, 2016)
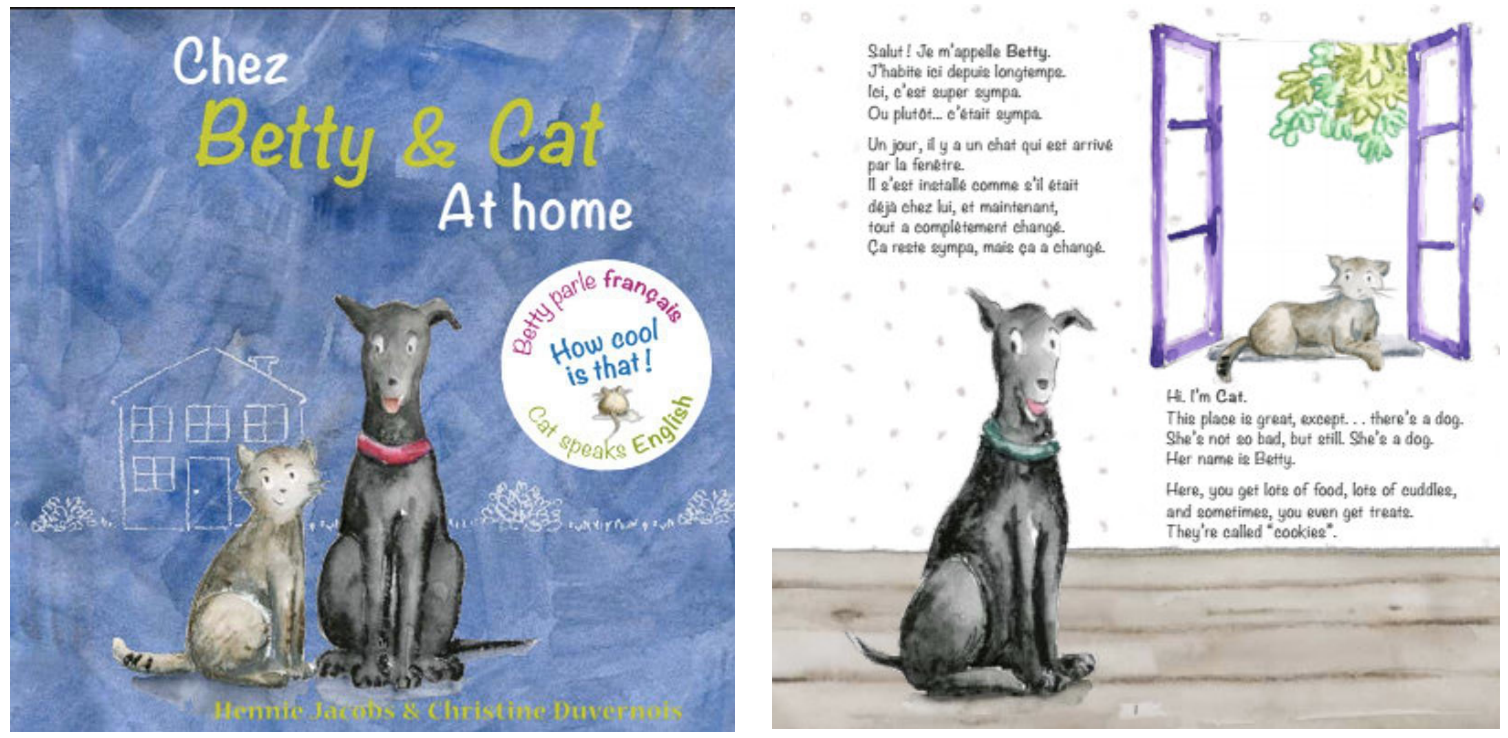

In each case, participants read aloud from parts of both books. We selected the first eight pages of each text in order for participants to provide us with an example of their reading of each text type, and to allow them to begin to follow the emerging story. After every page, we asked each participant to share with us what they had done to make sense of the text, and provided a clarifying prompt where needed to understand what students had done if there were parts of the text that they did not understand. Following each text, we asked readers to complete a set of multiple-choice questions. Each set included a mix of two types of questions; one type could be answered by identifying direct information within the text, while the other type required readers to make inferences about information within the text. The integrated text was followed by seven 
questions, and the translated text was followed by eight. Lastly, after they completed the comprehension questions for each text, we asked in a retrospective portion of the interview to provide general comments about what they had done to make sense of each text through general questions about the books as a whole, rather than specific passages within them.

We audio-recorded each session (read-aloud and retrospective interview) in order to produce verbatim transcriptions as data sources for our analysis. In order to identify reading strategies, we used a moderate inductive approach (Anadón \& Savoie-Zajc, 2009). Our analysis thus relied on both a classification of reading strategies used with monolingual text (Jiménez et al., 1996), and a set of cross-linguistic reading strategies that emerged from our previous work on dual-language books (Thibeault \& Matheson, 2020). We also allowed for the emergence of codes and themes from the data as we were coding.

For each of the three cases selected for this study, we began our deductive analysis by first noting every instance where the participants used a reading strategy according to our classifications (Jiménez et al., 1996; Thibeault \& Matheson, 2020). Next, we engaged in our inductive analysis by noting every instance where participants had provided a strategy that had yet to be incorporated in our typology. We used this approach in this order across both the read aloud sessions and retrospective interviews, for all three cases. After agreeing on our approach to coding the data, the two researchers independently recoded each of the transcripts across the three cases, which resulted in a 91\% interrater agreement, with any disagreements being resolved through discussion. The complete list of reading strategies, as well as definitions, can be seen in Table 1.

\section{Table 1}

Definitions of Reading Strategies

\begin{tabular}{|c|c|}
\hline Reading Strategy & Definition \\
\hline \multicolumn{2}{|c|}{ Monolingual Strategies } \\
\hline Focusing on vocabulary - French & Referring to specific French words in the text \\
\hline Focusing on vocabulary - English & Referring to specific English words in the text \\
\hline Decoding - French & $\begin{array}{l}\text { Applying knowledge of letter-sound } \\
\text { relationships to read French words }\end{array}$ \\
\hline Decoding - English & $\begin{array}{l}\text { Applying knowledge of letter-sound } \\
\text { relationships to read English words }\end{array}$ \\
\hline Demonstrating awareness & $\begin{array}{l}\text { Recognizing instances of comprehension or } \\
\text { miscomprehension }\end{array}$ \\
\hline Invoking prior knowledge & $\begin{array}{l}\text { Referring to knowledge constructed prior to } \\
\text { reading the text }\end{array}$ \\
\hline Affective response & Providing an affective response to the text \\
\hline Making inferences & $\begin{array}{l}\text { Drawing a conclusion based on textual } \\
\text { evidence and reasoning }\end{array}$ \\
\hline Using context (within same language) & Using a passage from the text to understand \\
\hline
\end{tabular}




\begin{tabular}{|c|c|}
\hline & another passage written in the same language \\
\hline Re-reading & $\begin{array}{l}\text { Reading a passage an additional time in order } \\
\text { to better understand it }\end{array}$ \\
\hline Asking questions & $\begin{array}{l}\text { Interrogating oneself or the interviewer about } \\
\text { an element in the text }\end{array}$ \\
\hline Use of pictures & $\begin{array}{l}\text { Referring to pictures to make meaning of the } \\
\text { text }\end{array}$ \\
\hline Predicting/confirming & $\begin{array}{l}\text { Constructing meaning from the text by making } \\
\text { informed predictions and verifying their } \\
\text { accuracy }\end{array}$ \\
\hline Skipping words or passages - French & $\begin{array}{l}\text { Moving ahead in the text in order to avoid a } \\
\text { specific French word or words }\end{array}$ \\
\hline Skipping words or passages - English & $\begin{array}{l}\text { Moving ahead in the text in order to avoid a } \\
\text { specific English word or words }\end{array}$ \\
\hline \multicolumn{2}{|c|}{ Cross-Linguistic Strategies } \\
\hline Using passages in other language & $\begin{array}{l}\text { Using passages in one language to make } \\
\text { meaning of passages written in the other }\end{array}$ \\
\hline Using cognates & $\begin{array}{l}\text { Using cognates that are not found in the text to } \\
\text { make meaning of an unknown word }\end{array}$ \\
\hline Using context (cross-linguistically) & $\begin{array}{l}\text { Using contextual clues found in the other } \\
\text { language to make meaning of passages in one } \\
\text { language }\end{array}$ \\
\hline Using structure & $\begin{array}{l}\text { Relying on the structural features of the dual- } \\
\text { language text to understand how languages } \\
\text { interact in the text }\end{array}$ \\
\hline Paraphrasing through translation & $\begin{array}{l}\text { Translating passages from the text in the other } \\
\text { language }\end{array}$ \\
\hline
\end{tabular}

\section{Results}

To present the results, we will showcase the strategies that each of our three focal readers deployed as they read dual-language books. To do so, we will first provide the number of times each strategy was used. This quantitative presentation of strategies, for each student, will be followed with the presentation of different verbatim excerpts, which we deem pertinent and representative of the strategies most deployed by each reader.

\section{Kaya's Profile}

Our first focal reader, Kaya, was 8 years old and in Grade 3 at the time of data collection. She predominantly speaks English at home, though she practices her French from time to time when she speaks with her mother. She has been enrolled in French immersion since Kindergarten. Following readings, Kaya scored 6/8 on the translated text comprehension questions, and $2 / 7$ on the integrated text comprehension questions, for a total of $8 / 15$. In Table 2 , 
we have inserted the reading strategies that Kaya deployed as she read both the translated and integrated texts.

\section{Table 2}

Kaya's Reading Strategies

\begin{tabular}{|c|c|c|c|c|c|}
\hline Monolingual Strategies & TT & IT & Cross-Linguistic Strategies & TT & IT \\
\hline Focusing on vocabulary - French & 6 & 3 & Using passages in other language & 4 & 2 \\
\hline Focusing on vocabulary - English & 3 & - & Using cognates & 1 & - \\
\hline Decoding - French & 2 & 1 & $\begin{array}{l}\text { Using context (cross- } \\
\text { linguistically) }\end{array}$ & - & - \\
\hline Decoding - English & 2 & 1 & Using structure & - & - \\
\hline Demonstrating awareness & 12 & 7 & Paraphrasing through translation & - & - \\
\hline Invoking prior knowledge & - & 1 & & & \\
\hline Affective response & - & 1 & & & \\
\hline Making inferences & - & - & & & \\
\hline $\begin{array}{l}\text { Using context (within same } \\
\text { language) }\end{array}$ & - & - & & & \\
\hline Re-reading & - & - & & & \\
\hline Asking questions & - & - & & & \\
\hline Use of pictures & - & - & & & \\
\hline Predicting/confirming & - & - & & & \\
\hline $\begin{array}{l}\text { Skipping words or passages - } \\
\text { French }\end{array}$ & - & - & & & \\
\hline $\begin{array}{l}\text { Skipping words or passages - } \\
\text { English }\end{array}$ & - & - & & & \\
\hline
\end{tabular}

Note. (-) indicates strategy was never used by the participant. $\mathrm{TT}=$ translated text. IT $=$ integrated text.

For the translated text, we identified seven different strategies that Kaya used. Demonstrating awareness was the most commonly used strategy; throughout her interview regarding the translated text, Kaya reported about her awareness of her gaps in comprehension (e.g., "I don't know what these two words mean") and where she understood the words she read (e.g., "I didn't have any problems with any words"). As she engaged with the book, she thus seemed to frequently focus on vocabulary, whether in French or in English. The following excerpt is a relevant example of her focus on vocabulary.

\section{Excerpt 1}

Kaya I'm not sure what this one means. 


\begin{abstract}
Researcher Okay. Which one? Can you read it?
Kaya "Craintive."

Researcher Okay. Is there anything that helped you?

Kaya I think it might be the same thing as this.

Researcher Okay, which is?

Kaya "Alarmed"

$(\ldots)$

Researcher What makes you think they are the same ones?

Kaya Because they are both the start of the sentence.

In this dialogue, three codes were used. As we can see, Kaya first demonstrates awareness when she states that she does not understand the word "craintive." By so doing, she focuses on French vocabulary and, to understand the unknown word, she relies on the equivalent English passage. She further noticed that "craintive" and "alarmed" were both positioned at the beginning of sentences; she was therefore able to match the words according to their position in
\end{abstract} the sentence.

As far as the integrated text is concerned, we also identified seven different strategies that Kaya used. Again, the demonstration of awareness is the most notable one; Kaya often mentioned which words she did or not did understand (e.g., "I understand everything and I didn't know what was 'sympa""). She once invoked prior knowledge ("It doesn't really sound like a word and I just thought it was a name after I read it") and manifested an affective response ("I really like the drawings"). Overall, the strategies she deployed seem quite similar for the integrated text and the translated text. The following excerpt is taken from the interview conducted after she read the integrated text; just as she did for the translated text, she mentions the use of equivalent passages in one language to make meaning of unknown words in the other.

\title{
Excerpt 2
}

"It's the words and when I didn't understand the English or the French ones I just looked at the English and when I didn't understand the English and compare it, and then if I didn't understand a French then I just looked at the English."

\section{Maria's Profile}

Our second focal reader, Maria, was an 8-year-old, Grade 3 student when she took part in our study. She predominantly speaks English at home, though she mentioned that she sporadically practices her French with her parents. Since kindergarten, she has been schooled in French immersion, in Saskatchewan. Maria scored 7/8 on the translated text comprehension questions, and 6/7 on the integrated text comprehension questions, for a total score of 13/15. Table 3 highlights the strategies that she mentioned using as she was reading both the translated and integrated texts. 


\section{Table 3}

Maria's Reading Strategies

\begin{tabular}{|c|c|c|c|c|c|}
\hline Monolingual Strategies & TT & IT & Cross-Linguistic Strategies & TT & IT \\
\hline $\begin{array}{l}\text { Focusing on vocabulary - } \\
\text { French }\end{array}$ & 2 & - & Using passages in other language & 2 & - \\
\hline $\begin{array}{l}\text { Focusing on vocabulary - } \\
\text { English }\end{array}$ & 2 & - & Using cognates & - & - \\
\hline Decoding - French & - & 6 & Using context (cross-linguistically) & - & - \\
\hline Decoding - English & 1 & - & Using structure & - & 1 \\
\hline Demonstrating awareness & 3 & 3 & Paraphrasing through translation & - & - \\
\hline Invoking prior knowledge & - & - & & & \\
\hline Affective response & - & - & & & \\
\hline Making inferences & 1 & 1 & & & \\
\hline $\begin{array}{l}\text { Using context (within same } \\
\text { language) }\end{array}$ & - & - & & & \\
\hline Re-reading & 2 & - & & & \\
\hline Asking questions & 2 & 1 & & & \\
\hline Use of pictures & 3 & 7 & & & \\
\hline Predicting/confirming & - & 1 & & & \\
\hline $\begin{array}{l}\text { Skipping words or passages - } \\
\text { French }\end{array}$ & - & - & & & \\
\hline $\begin{array}{l}\text { Skipping words or passages - } \\
\text { English }\end{array}$ & 5 & 1 & & & \\
\hline
\end{tabular}

Note. (-) indicates strategy was never used by the participant. TT $=$ translated text. IT = integrated text.

In her reading of the translated text, we identified 10 different strategies that Maria used. Her most recurrently used strategy was skipping words or passages in English. This was somewhat surprising considering that English was her dominant language and that she never used the equivalent strategy for words or passages in French. In fact, at the beginning of the reading session, she faced difficulties as she was reading the English noun chihuahua, and relied on the strategy asking questions to pose the researcher "Can I skip it?" After the interviewer told her to "do what you would do if you were reading on your own," she skipped the word. She went on using the strategy four more times, always with English words, and mentioned that she was doing so because some of these words were "very long."

Though Maria only seemed to use passages in the other language twice when she read the translated text, she explicitly talked about this particular strategy in the post-interview. 


\section{Excerpt 1}

Researcher Is there anything else you did to make you understand better?

(...)

Maria Using the English words to translate in French or the opposite of that.

Researcher So you did both of this?

Maria Yeah.

Researcher How did the English help you with the French?

Maria $\quad$ Eum...If I knew the English word...If I knew the English word in English but not in French it will help me.

Researcher And how did the French help you with the English?

Maria $\quad$ Eum...If I knew what it was in French but not in English.

Interestingly enough, in this excerpt, she mentions that she uses both English and French vocabulary to make meaning of unknown words in the other language. As such, on the one hand, she skipped a few words when she read passages in English and, on the other, she mentions that both French and English can be used to understand passages of the book. Though we cannot conclude that she uses her knowledge of the French words to specifically understand the English words that she skipped, we can nonetheless contend that Maria comprehends the scaffolding potential of English and French passages in the translated text. This, at the very least, provides her with a cognitive tool that she can utilize when she skips an unknown English word.

We identified eight distinct reading strategies that Maria used for the integrated text. This time, the most predominant strategy was the use of pictures, followed with decoding French words. In fact, throughout the reading session of the integrated text, these two strategies seemed to be consistently employed by Maria, who often relied on one of them or both concurrently. She furthermore deployed a low number of cross-linguistic strategies; she only noticed the integrated structure once when she said "The cat is English, but the dog is French." In the post-interview, she developed her thoughts in regard to this particular textual structure.

\section{Excerpt 2}

Researcher Did the presence of two languages in this book help you understand what you were reading?

Maria $\quad$ Eum... No, not really because it's two different sentences [...]. Like this one is like different. It's like one of them is the dog and one of them is the cat. And so, they will be different on the same sentences in English and French.

Researcher And so that, you don't think that the English could help you with the French, and vise versa?

Maria With this one, no. Not really.

Researcher Okay.

Maria But kind of because they are both talking about the same things but not in like the... not the... it not written the same way. But they're both talking 
about the same things but not exactly.

This excerpt is particularly interesting because it showcases Maria's conflicting views regarding the integrated book's structure and its potential for supporting her reading comprehension. On the one hand, she is aware that English and French passages are not entirely equivalent in the book. On the other, she also knows that both protagonists are narrating the same events and that the cat's perspectives are in fact complementary to the dog's perspectives.

\section{Karly's Profile}

Our last focal reader, Karly, was also eight years old and in grade 3 at the time of data collection. Like Kaya and Maria, she has been enrolled in French immersion since kindergarten. She exclusively speaks English at home. Karly scored 7/8 on the translated text comprehension questions, and 7/7 on the integrated text comprehension questions, for a total score of 14/15. In Table 4, we have inserted the reading strategies that Karly used as she read both the translated and integrated texts.

\section{Table 4}

Karly's Reading Strategies

\begin{tabular}{|c|c|c|c|c|c|}
\hline Monolingual Strategies & TT & IT & Cross-Linguistic Strategies & TT & IT \\
\hline Focusing on vocabulary - French & 4 & 5 & Using passages in other language & 1 & - \\
\hline Focusing on vocabulary - English & 1 & 2 & Using cognates & - & 2 \\
\hline Decoding - French & - & 6 & Using context (cross-linguistically) & - & 1 \\
\hline Decoding - English & 1 & - & Using structure & - & 2 \\
\hline Demonstrating awareness & 9 & 8 & Paraphrasing through translation & 6 & 2 \\
\hline Invoking prior knowledge & - & 2 & & & \\
\hline Affective response & - & - & & & \\
\hline Making inferences & - & - & & & \\
\hline $\begin{array}{l}\text { Using context (within same } \\
\text { language) }\end{array}$ & 2 & 1 & & & \\
\hline Re-reading & 2 & - & & & \\
\hline Asking questions & - & 2 & & & \\
\hline Use of pictures & 3 & 2 & & & \\
\hline Predicting/confirming & - & - & & & \\
\hline Skipping words or passages - French & - & - & & & \\
\hline $\begin{array}{l}\text { Skipping words or passages - } \\
\text { English }\end{array}$ & - & - & & & \\
\hline
\end{tabular}

Note. (-) indicates strategy was never used by the participant. TT $=$ translated text. IT $=$ integrated text. 
For the translated text, we identified nine different strategies that Karly used. Similar to Maria, demonstrating awareness was the most often reported strategy, and Karly used it to communicate that she did not understand particular words in French, though she also identified a word in English that was unfamiliar. She explicitly shared that she is better in English than French because it was her "first language." Concerted efforts to make sense of the French text were evident through phrases including "Okay it makes more sense"-something she uttered after she read the English passage that followed an unclear French passage. Karly also regularly paraphrased through translation while reading the translated text - a strategy that seemed to characterize her approach to reading the translated text. The following excerpt is a relevant example of her regular attempts to understand the story by paraphrasing the French text through translation:

\section{Excerpt 1}

"La petite souris salua Soso et s'approcha. So like it says 'hi' or euh... The little mouse waved and came toward the house. Oh okay, so kind of 'hi.",

In this passage, Karly uses two different strategies-paraphrasing through translation and demonstrating awareness. Following the French passage, Karly attempts to translate it, suggesting that she is trying to understand it before "checking" with the English passage. Her use of "or euh..." in her initial paraphrase, coupled with the utterance "oh okay, so kind of "hi"" together suggest that she is demonstrating awareness of her level of understanding of the French text. It appeared that Karly was regularly challenging herself to understand the French text, and then using the English text to check her comprehension. Though Karly also used other strategies including focusing on vocabulary in French, it was her paraphrasing through translation and demonstrations of awareness that seemed to best characterize her reading of the translated text. It is also noteworthy that Karly, as seen in this passage, often verbalized strategies without the researcher's prompt.

With the integrated text, we identified 12 distinct strategies with Karly. She again most commonly demonstrated awareness, doing so a total of eight times. Similar to the translated text, she reported about her awareness of difficulty with specific words in French. Though Karly did attempt to paraphrase through translation in a couple of instances, she seemed to recognize that without the English equivalent passages, she would need to rely on a number of other strategies to build meaning. As seen in Table 4, strategies including asking questions, use of structure, invoking prior knowledge, and use of cognates were reported with the integrated text, but not with the translated text. Karly's reading of the integrated text was best characterized by the use of multiple strategies together to understand unclear passages of text. Excerpt 2 illustrates an example of multiple strategies that Karly used together as an attempt to make sense of the text:

\section{Excerpt 2}

Well, for "ronron, ronron" I didn't understand but there was a "purrrr" over here and this seems like a sound...So, I'm guessing this is "purrrr". So, that helped me understand a little bit more and she also said it in the other paragraph so...I'm guessing that means "purrrr."

In this passage, Karly demonstrates awareness of some confusion related to the term "ronron." This is a focus on French vocabulary, and Karly reports that she is using the picture that accompanies the text wherein the cat is depicted making a "purrrr" sound. Karly infers that it 
"seems like a sound" based on what she has pieced together from various textual clues and her interpretation of them. She also uses context cross-linguistically by recalling that the same term was used in an earlier paragraph. After the integrated text reading, Karly shared that she needed to rely on different strategies in the absence of having an equivalent English passage to assist her in building meaning - this dynamic approach to reading this style of text was evident throughout her reading and reporting with the integrated text.

\section{Discussion}

In sum, across the three cases, the differences among Kaya, Maria, and Karly in their repertoire of strategies used offer a glimpse of their approaches to reading. In considering how these three focal participants compare as readers, one might consider that they position themselves on different parts of a continuum of bilingual reading development. On the one side of the continuum, Kaya represents a reader that does not seem to make adjustments to how they read text based on the demands of the text. Further, Kaya uses a limited range of strategies. While the reasons for Kaya's notable lack of adjustment and range are unclear, this unresponsive style of reading is considered to be less effective than more dynamic and responsive approaches (Matheson \& MacCormack, 2021; Paris \& Jacobs, 1984). In another part of the continuum, one that demonstrates a more effective use of reading strategies, reading is characterized by greater responsiveness and range. Maria represents a more dynamic reader-one that uses different strategies based on the style or structure of the text she is reading. Despite greater range and responsiveness, reading strategy use is mostly monolingual for her during the interview that took place as she was reading. In the retrospective interview, she did mention that both English and French could be used to understand words in the other language, though such cross-linguistic strategies were not apparent as she read. At the other end of the continuum, reading is dynamic and it involves a range of strategies, but it represents a shift to a heavier reliance on crosslinguistic strategies. As noted by researchers (Alsheikh, 2011; Jiménez et al., 1996), such behaviours can be quite effective because they involve reading strategies that combine L1 and L2 linguistic skills.

Though our measure for comprehension has not been validated as it was designed for the two texts we used in the study, the results may offer some additional insight. Kaya, our first focal student, scored 8 out of 15 in her total reading comprehension score. Maria and Karly scored 13 and 14 respectively, suggesting that their dynamic reading styles seemed to lead to greater comprehension. Further, Kaya scored 6 out of 8 with the translated text, but only 2 out of 7 with the integrated text. Kaya's lack of adjustment in her approach to reading the integrated text supports the idea that reading can be effective when readers transfer strategies across their L1 and L2 (Bourgoin, 2015), but that perhaps it is not effective when the approach does not match the demands (Mokhtari \& Sheorey, 2002). Karly and Maria had similar overall scores; however the noted difference with Karly's proclivity for offering unprompted reports of her reading activity may distinguish readers of this study. When readers are comfortable using a mix of monolingual and cross-linguistic strategies, they may be more confident in using them as we saw with Karly.

Another interesting result that emerged from this study is about the need for prompting. Unlike Maria and Kaya, Karly did not require any prompting while reading, and instead offered unsolicited verbal reporting of her thinking throughout the reading of both texts. While she was able to respond to questions following each passage about her thinking, she also reported about her thinking within passages. This could have been the result of stronger language abilities, 
particularly within the French language, and therefore, greater confidence in comparison to her peers. Also compared to her peers, Karly used a greater range of cross-linguistic strategies. While Karly and Maria used a comparable number of strategies across both text types, Maria relied mainly on monolingual strategies, where Karly used both monolingual and cross-linguistic strategies across both texts. Surprisingly, Karly was the only participant who reported speaking exclusively English at home.

\section{Limitations}

Like all studies, ours have limitations that we must put forward. Considering the exploratory purpose of the research and the limited number of focal students we described for this paper, our objective was not to showcase an exhaustive portrait of reading strategies for dual-language text; the typology we used will likely have to be completed and nuanced as other researchers zero in on how bilingual students engage in dual-language reading. In this perspective, we did not focus on our focal readers' general competency level in reading, nor did we situate them in regard to their peers' reading levels. Future research focusing on duallanguage reading could thus zero in on the reading strategies used by proficient and less effective readers as they engage with dual-language books. That way, we will be able to comprehend the strategies that are predominately deployed by stronger readers and provide teachers with concrete ways to helps their students as they read dual-language text. Our focal readers, moreover, happened to be all girls. Subsequent research should examine both male and female students to obtain a broader representation of how children learn and interact with dual-language texts.

In this study, students had to read the integrated book immediately after they read the translated text. We also did not tell students about the structural differences between each book before they started reading the second one. It is thus possible that some of the participants did not have the reflex to adapt their reading behaviours as they engaged with the integrated text. That being said, as we know that efficient readers tend to adapt their strategy more easily (Mokhtari \& Sheorey, 2002), this procedure allowed us to document the adaptation of our participants' reading strategies as they read different types of dual-language books. Finally, it is important to note that the measures we designed for reading comprehension of each text type have not been validated. While they may offer additional insight into the reading profiles of our focal students, we do not contend that they can serve as stand-alone measures of reading ability.

\section{Implications and Conclusion}

In their efforts to support the bilingual reading development of their students, we suggest that French immersion teachers should encourage students to draw on their L1 as needed. It is evident from our results that readers, as seen with Maria, can be dynamic, but largely monolingual in the strategies they use. Given the identified value of drawing on both L1 and L2 skills when learning an L2 (Ballinger, 2013; Swain \& Lapkin, 2013), we argue that teachers should model how they make adjustments to their reading behaviour based on the text, as well as how they use crosslinguistic skills to construct meaning while reading. Further, teachers could explain their thinking behind their approaches and actions in order to show students both how and why they approach reading as they do. We believe that such practices will not only support students in the development of reading skills in French, but that they will also help them understand the potential of cross-linguistic reflections as they read both monolingual and dual-language text. 


\section{References}

Alsheikh, N. O. (2011). Three readers, three languages, three texts: The strategic reading of multilingual and multiliterate readers. The Reading Matrix, 11(1), 34-53.

Anadón, M., \& Savoie-Zajc, L. (2009). Introduction. Recherches qualitatives, 8(1), 1-7.

Anastasiou, D., \& Griva, E. (2009). Awareness of reading strategy use and reading comprehension among poor and good readers. Elementary Education Online, 8, 283-297.

Armand, F., Gosselin-Lavoie, C., \& Combes, É. (2016). Littérature jeunesse, éducation inclusive et approches plurielles des langues. Synergies Canada, 9, 1-5. https://doi.org/10.21083/nrsc.v0i9.3675

Aydinbek, C. (2021). The effect of instruction in reading strategies on the reading achievement of learners of French. Eurasian Journal of Educational Research, 91, 321-338. https://doi.org/10.14689/ejer.2021.91.15

Ballinger, S. (2013). Towards a cross-linguistic pedagogy: Biliteracy and reciprocal learning strategies in French immersion (Unpublished doctoral dissertation). McGill University, Montreal, Canada.

Bourgoin, R. (2015). Reading strategies: At risk and high performing immersion learners. CARLA Immersion Project Research to Action Brief, September 2015. Retrieved from http://carla.umn.edu/immersion/briefs/Bourgoin Sept15.pdf

Brunelle, J., \& Tondino, T. (2017). Enchantée/Pleased to meet you! Montreal, QC: Les images de la libertée/Lady Liberty Pictures.

Cisco, B. K., \& Padrón, Y. (2012). Investigating vocabulary and reading strategies with middle grades English language learners: A research synthesis. Research in Middle Level Education, 36(4), 1-23.

Cormier, G. (2018). Portraits of French secondary education in Manitoba (Unpublished doctoral dissertation). University of Manitoba, Winnipeg, Canada.

Cummins, J. (2008). Teaching for transfer: Challenging the two solitudes assumption in bilingual education. In N. H. Hornberger (Ed.), Encyclopedia of Language and Education ( $2^{\text {nd }}$ ed., pp. 65-75). Springer.

Domke, L. M. (2019). Exploring dual-language books as a resource for children's bilingualism and biliteracy development (Unpublished doctoral dissertation). Michigan State University, USA.

Duff, P. A. (2008). Case study research in applied linguistics. Lawrence Erlbaum Associates.

Edwards, V., Monaghan, F., \& Knight, J. (2000). Books, pictures, and conversations: Using bilingual multimedia storybooks to develop language awareness. Language Awareness, 9(3), 135-146. https://doi.org/10.1080/09658410008667142

Ernst-Slavit, G., \& Mulhern, M. (2003). Bilingual books: Promoting literacy and biliteracy in the second-language and mainstream classroom. Reading Online, 7(2), 1-15.

Fleuret, C., \& Sabatier, C. (2019). La littérature de jeunesse en contextes pluriels : perspectives interculturelles, enjeux didactiques et pratiques pédagogiques. Recherches et applications, 65, 95-111. 
Frid, B. (2018). Reading comprehension and strategy use in forth-and fifth-grade French immersion students (Unpublished masters thesis). Western University, London, Canada.

Gosselin-Lavoie, C. (2016). Lecture de livres bilingues par six duos parent-enfant allophones du préscolaire : description des lectures et des interactions et relations avec l'acquisition du vocabulaire (Unpublished master's thesis). University of Montreal, Montreal, Canada.

Jacobs, H., \& Duvernois, C. (2006). Chez Betty \& Cat at home. Hennie Jacobs.

Jiménez, R., Garcia, G. E., \& Pearson, D. P. (1996). The reading strategies of bilingual Latina/o students who are successful English readers: Opportunities and obstacles. Reading Research Quarterly, 31(1), 90-112.

Lau, K.- L. (2006). Reading strategy use between Chinese good and poor readers: A think-aloud study. Journal of Research in Reading, 29, 383-399. https://doi.org/10.1111/j.14679817.2006.00302.x

Matheson I. A., \& MacCormack, J. (2021). Avoiding left-to-right, top-to-bottom: An examination of high school students' executive functioning skills and strategies for reading non-linear graphic text. Reading Psychology, 42(1), 1-21. https://doi.org/10.1080/02702711.2020.1837313

Mokhtari, K., \& Sheorey, R. (2002). Measuring ESL students' awareness of reading strategies. Journal of Developmental Education, 25, 2-10.

Moore, D., \& Sabatier, C. (2014). Les approches plurielles et les livres plurilingues. De nouvelles ouvertures pour l'entrée dans l'écrit en milieu multilingue et multiculturel. Nouveauxc@hiers de la recherche en éducation, 17(2), 32-65. https://doi.org/10.7202/1030887ar

Naqvi, R., Thorne, K. J., Pfitscher, C. M., Nordstokke, D. W., \& McKeough, A. (2012). Reading dual language books: Improving early literacy skills in linguistically diverse classrooms. Journal of Early Childhood Research, 11(1), 3-15. https://doi.org/10.1177\%2F1476718X12449453

Paris, S. G., \& Jacobs, J. E. (1984). The benefits of informed instruction for children's reading awareness and comprehension skills. Child Development, 55(6), 2083-2093. https://doi.org/10.2307/1129781

Perregaux, C. (2009). Livres bilingues et altérité. Nouvelles ouvertures pour l'entrée dans l'écrit. Figurationen, 9(1-2), 127-139.

Read, K., Contreras, P. D., Rodriguez, B., \& Jara, J. (2021) ¿Read conmigo?: The effect of codeswitching storybooks on dual-language learners' retention of new vocabulary. Early education and development, 32(4), 516-533. https://doi.org/10.1080/10409289.2020.1780090

Robertson, L. H. (2006). Learning to read 'properly' by moving between parallel literacy classes. Language and Education, 20(1), 245-302. https://doi.org/10.1080/09500780608668709

Simoncini, K., Pamphilon, B., \& Simeon, L. (2019). The 'Maria' books: The achievements and challenges of introducing dual language, culturally relevant picture books to PNG schools. Language, Culture and Curriculum, 32(1), 78-93. https://doi.org/10.1080/07908318.2018.1490745 
Sneddon, R. (2009). Bilingual books—Biliterate children: Learning to read through duallanguage books. Trentham Books.

Swain, M., \& Lapkin, S. (2013). A Vygotskian sociocultural perspective on immersion education: The L1/L2 debate. Journal of Immersion and Content-Based Education, 1(1), 101-129. https://doi.org/10.1075/jicb.1.1.05swa

Taylor, L. K., Bernhard, J. K., Garg, S., \& Cummins, J. (2008). Affirming plural belonging: Building on students' family-based cultural and linguistic capital through multiliteracies pedagogy. Journal of Early Childhood Literacy, 8, 269-294. https://doi.org/10.1177\%2F1468798408096481

Thibeault, J., \& Matheson, I. A. (2020). The cross-linguistic reading strategies used by elementary students in French immersion as they engage with dual-language children's books. The Canadian Modern Language Review, 76(4), 375-394. https://doi.org/10.3138/cmlr-2019-0071

Thibeault, J., \& Quevillon-Lacasse, C. (2019). Trois modalités de réseaux littéraires pour enseigner la grammaire en contexte plurilingue. OLBI Working Papers, 10, 291-310. https://doi.org/10.18192/olbiwp.v10i0.3393

Turcotte, C., Giguère, M.-H., \& Godbout, M.-J. (2015). Une approche d'enseignement des stratégies de compréhension de lecture de textes courants auprès de jeunes lecteurs à risque d'échouer. Language \& Literacy, 17(1), 106-125. https://doi.org/10.20360/G2SW2B 